\title{
Borderline lepromatous leprosy
}

\section{Hanseníase borderline virchowiana}

\author{
Christiane Matsuo ${ }^{1}$ \\ Lisiane Nogueira ${ }^{3}$ \\ Mônica Nunes dos Santos ${ }^{5}$
}

\author{
Carolina Talhari ${ }^{2}$ \\ Renata Fernandes Rabelo ${ }^{4}$ \\ Sinesio Talhari ${ }^{6}$
}

\begin{abstract}
It is presented a case of borderline lepromatous leprosy with 4 years of evolution and cutaneous lesions of difficult diagnosis in the National Health System. The histopathological evaluation, which was essential for the diagnosis, showed disorganized granulomatous structures and multiple alcohol -acid resistant bacilli. Cases like the one described here are responsible for the contamination of cohabitants and the appearance of new cases of leprosy.

Keywords: Leprosy; Leprosy, bordeline Leprosy, lepromatous

Resumo: É apresentado caso de hanseníase borderline virchowiana com quatro anos de evolução e lesões cutâneas de difícil diagnóstico na rede de saúde. O exame histopatológico mostrando estruturas granulomatosas desorganizadas e múltiplos bacilos álcool-ácido resistentes foi essencial para o diagnóstico. Casos como o descrito possibilitam a contaminação dos conviventes e o surgimento de novos casos de hanseníase no futuro.

Palavras-chave: Hanseníase; Hanseníase dimorfa; Hanseníase Virchowiana
\end{abstract}

Borderline lepromatous leprosy manifests itself by a large number of lesions, with various aspects such as: infiltrations, plaques (some with the central region apparently spared), outer edges badly defined and nodules. ${ }^{1-3}$ Lesions are not so symmetrical as for lepromatous and there is tickening of a great number

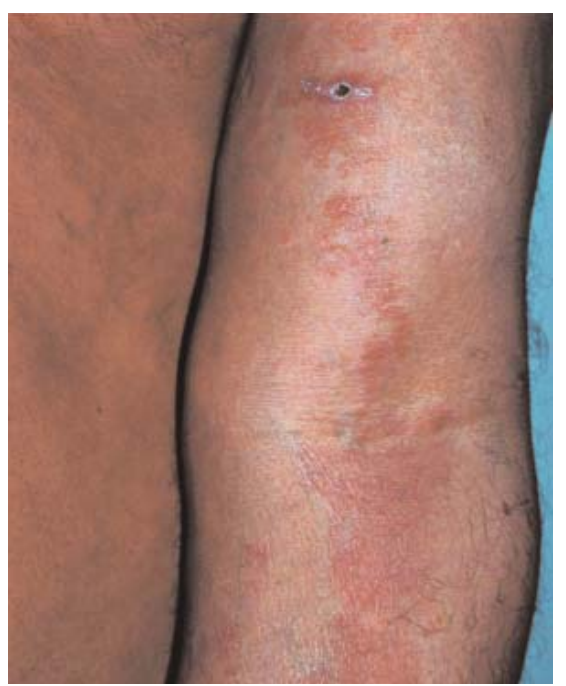

Figure 1: Plaques and erythemotous papules on the internal face of the left upper limb and progressing for four years of nerve trunks. ${ }^{1}$ Smear is positive, with inumerous bacilli. ${ }^{1-3}$ The clinical classification of borderline patients is, many times, as in the case presented here, (Figures 1 and 2) difficult. Cutaneous manifestations may not fit into the clinical patterns described or the histopathological exam is not compatible with the

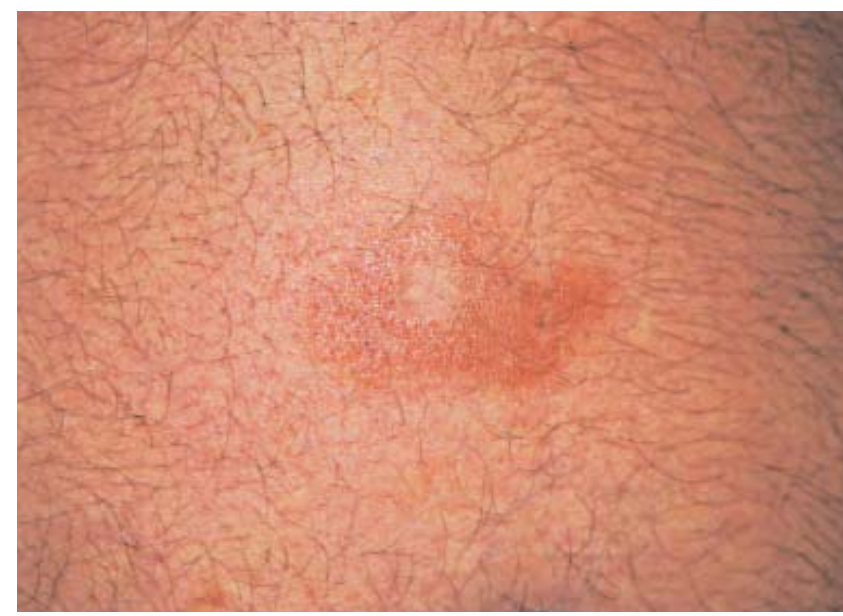

FIGURE 2: Erythematous plaque with outer edges badly defined and central region apparently spared, located on the abdomen

Approved by the Editorial Board and accepted for publication on 16.07.2010

* Work carried out in the Tropical Medicine Foundation of Amazonas - Manaus (AM), Brazil.

Conflict of interest: None / Conflito de interesse: Nenbum

Financial funding / Suporte financeiro: Fundação de Medicina Tropical do Amazonas

Specialist in Dermatology by the Brazilian Society of Dermatology - Dermatologist of the Tropical Medicine Foundation of Amazonas - Manaus(AM),Brazil. Doctorate - Dermatology professor of the State University of Amazonas - Manaus(AM),Brazil

MD- Dermatology resident of the Tropical Medicine Foundation of Amazonas Manaus(AM),Brazil

MD- Dermatology resident of the Tropical Medicine Foundation of Amazonas Manaus(AM),Brazil.

Doctorate in Tropical Medicine - Dermatologist of the Tropical Medicine Foundation of Amazonas - Manaus(AM),Brazil.

Doctorate in Dermatology - Director of the Tropical Medicine Foundation of Amazonas - Manaus (AM), Brazil. 
clinical classification. ${ }^{4,5}$ In these cases, the MHB classification is simply adopted and the patient is treated according to smear result (Figures 3 e 4 ) or according to the classification of the World Health Organization in accordance with the number of lesions ${ }^{1}$.

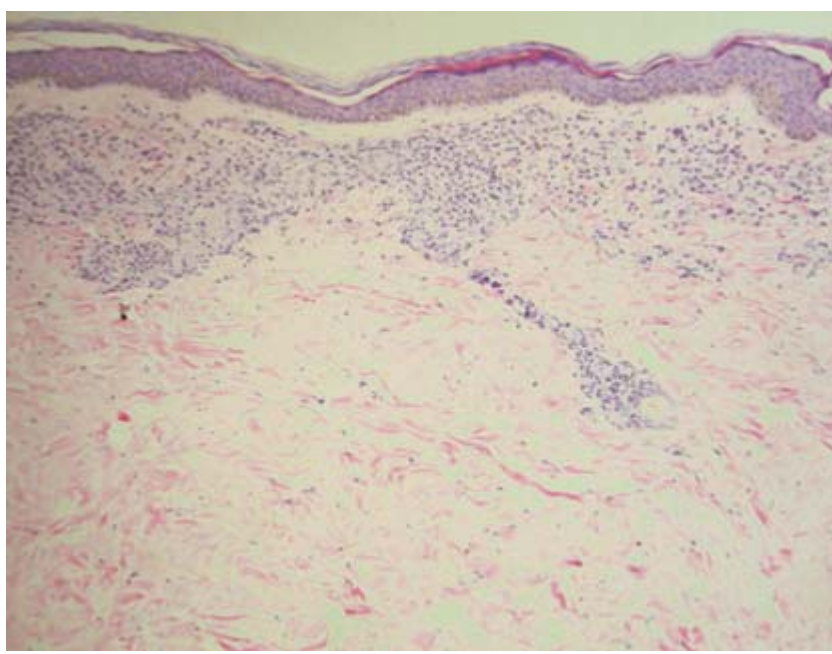

FIGURE 3: Histopathological exam shows atrophic epidermis, band of Unna and loose granulomatous structures containing vacuolated histiocytes (hematoxylin and eosin, 200X)
Undiagnosed patients with active tuberculosis evolving for years, as the case reported here, enable the contamination of cohabitants and the emergence of new cases of Hansen's disease in the future. ${ }^{1}$

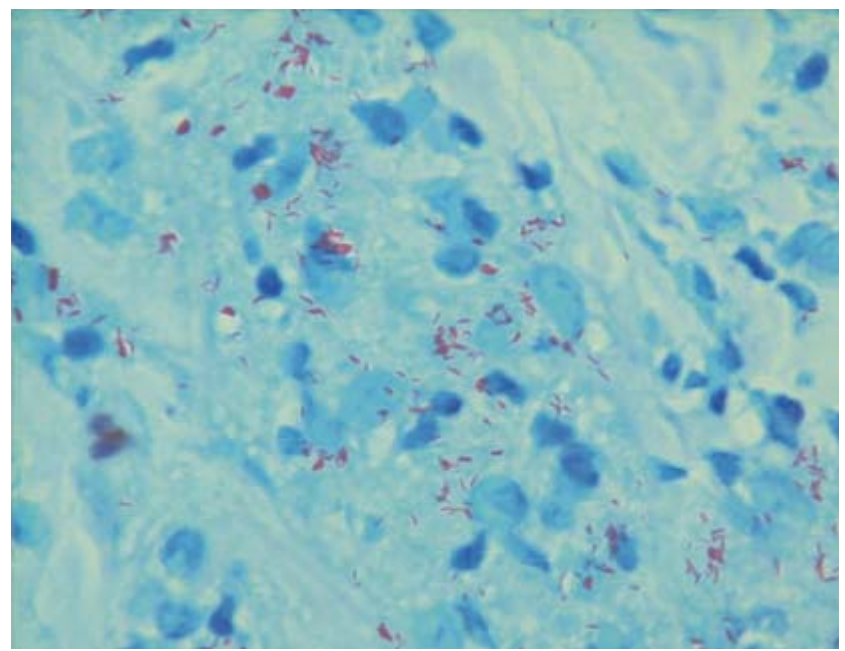

FIGURE 4: Through Wade staining many alcohol-acid resistant bacilli, isolated and forming globi can be observed. (1000X)

\section{REFERENCES}

1. Talhari S, Neves RG, de Oliveira MLW, de Andrade ARC, Ramos AMC, Penna GO, Talhari AC. Manifestações cutâneas e diagnóstico diferencial. In: Talhari S, Neves RG, Penna GO, de Oliveira MLV, editores. Hanseníase. 4 ed. Manaus: Editora Lorena; 2006. p. 21-58.

2. Foss NT. Hanseníase: aspectos clínicos, imunológicos e terapêuticos. An Bras Dermatol. 1999;74:113-9.

3. Walker SL, Lockwood DN. Leprosy. Clin Dermatol. 2007;25:165-72.

4. Ridley DS, Jopling WH. A classification of leprosy for research purposes. Lepr Rev. 1962;33:119-28.
5. Ridley DS, Jopling WH. Classification of leprosy according to immunity. A five-group system. Int J Lepr Other Mycobact Dis. 1966;34:255-73.

MAILING ADDRESS / ENDEREÇO PARA CORRESPONDÊNCIA: Carolina Talbari Avenida Pedro Texeira, 25, Dom Pedro 69040000 Manaus, AM, Brazil. 